\title{
LEGISLATIVA EM MATÉRIA URBANÍSTICA E A GESTÃO DEMOCRÁTICA DAS POLÍTICAS URBANAS
}

\section{COMMITTEE ON URBANISTIC MATTERS AND THE DEMOCRATIC MANAGEMENT OF URBAN POLICIES}

Sérgio Laguna PEREIRA ${ }^{1}$

ISSUE DOI: $10.21207 / 1983.4225 .486$

\section{RESUMO}

Adotando como ponto de partida a transição do paradigma ecológico ao paradigma socioespacial em sociologia urbana, cujas diferenças impactam significativamente o modo de compreensão dos problemas urbanos, o presente artigo examina o fenômeno da segregação espacial urbana e seus reflexos na estruturação da cidade e, de modo mais especial, na produção legislativa urbanística. Apoiado em base lógico-investigativa orientada pelo método indutivo e valendo-se de pesquisa bibliográfica, o estudo concluiu pela necessidade de implementação de mecanismos de participação social democrática no

${ }^{1}$ Graduado em Ciências Jurídicas e Sociais pela Universidade Federal do Rio Grande do Sul (2006). Especialista em Advocacia Pública pela AVM Faculdades Integradas e Instituto para o Desenvolvimento Democrático (2015). Mestrando no Programa de Pós-Graduação em Ciência Jurídica da Universidade do Vale do Itajaí - PPCJ/UNIVALI (CAPES 5), Linha de Pesquisa Direito, Desenvolvimento Urbano e Meio Ambiente (desde 2016). Procurador do Estado na Procuradoria Geral do Estado de Santa Catarina desde 2010. Entre 2013 e 2016, esteve lotado e em exercício na Procuradoria Especial em Brasília, com atuação na representação do Estado perante o Supremo Tribunal Federal e Tribunais Superiores. Desde agosto de 2016, atua no assessoramento do Procurador-Geral do Estado de Santa Catarina em Florianópolis/SC. E-mail: laguna@pge.sc.gov.br 
processo de planejamento urbano, os quais são tidos como elementos indispensáveis para a mitigação dos efeitos da segregação, para a redução de desigualdades e para a efetivação do direito à cidade.

Palavras-chave: Sociologia urbana; Segregação espacial urbana; Planejamento urbano; Gestão democrática urbana.

\begin{abstract}
Taking as a starting point the transition from the ecological paradigm to the socio-spatial paradigm in urban sociology, whose differences significantly impact the understanding of urban problems, this paper examines the phenomenon of urban spatial segregation and its repercussions in structuring of the city and, more especially, in the urban planning legislation. Based on a logical-research base guided by the inductive method and using bibliographical research, the study concluded that it is necessary to implement mechanisms of democratic social participation in the urban planning process, which are considered indispensable elements for the mitigation of the effects of segregation, reduction of inequalities and the realization of the right to the city.
\end{abstract}

Keywords: Urban sociology; Urban spatial segregation; Urban planning; Urban democratic management.

\title{
INTRODUÇÃO
}

A segregação espacial urbana - entendida como um processo em que diferentes grupos hegemônicos se distribuem geograficamente de modo desigual e transformam, também assimetricamente, o espaço urbano - produz significativos efeitos na forma como as pessoas usufruem da cidade ou se beneficiam dos equipamentos públicos urbanos.

O propósito do presente artigo é examinar como a segregação espacial urbana impacta a produção do direito urbanístico; propõem-se, ao final, instrumentos aptos à mitigação de tais efeitos, propiciando-se uma apropriação mais democrática do espaço urbano.

Na primeira seção, analisar-se-á a recente mudança paradigmática da sociologia urbana, com a passagem do paradigma ecológico ao paradigma socioespacial, fenômeno que provoca modificações no modo como se devem examinar as questões urbanas. Na segunda seção, analisarse-á no que consiste e de que forma se opera a segregação espacial urbana, em especial no que concerne aos efeitos não democráticos que ela produz na produção legislativa urbanística. Por fim, na terceira seção, examinarse-á a importância do processo democrático de planejamento urbano como elemento intrínseco à efetivação do direito à cidade. 
Recorrendo à pesquisa bibliográfica, o presente trabalho terá base lógico-investigativa apoiada no método indutivo ${ }^{2}$, tendo sido utilizadas, ainda, as técnicas do referente ${ }^{3}$, da categoria ${ }^{4}$ e do conceito operacional ${ }^{5}$.

\section{A TRANSIÇÃO DO PARADIGMA ECOLÓGICO AO PARADIGMA SOCIOESPACIAL EM SOCIOLOGIA URBANA}

A sociologia urbana experimentou, nas últimas décadas, uma transição paradigmática ${ }^{6}$ capaz de produzir significativas mudanças no estudo das questões urbanas. Passou-se do paradigma ecológico para o novo paradigma socioespacial. De acordo com o paradigma ecológico, adotavase uma visão ecológica do comportamento humano na cidade. Sob influência do darwinismo social, a cidade era tida como uma ordem natural, claramente identificada com ambientes analisados pela biologia. Estudavamse, assim, as relações entre as pessoas na cidade a partir de processos de distribuição, acomodação, competição, seleção e simbiose, a exemplo das relações entre animais ou plantas na natureza. "A diferença estaria no fato

\footnotetext{
${ }^{2}$ MÉTODO INDUTIVO: base lógica da dinâmica da Pesquisa Científica que consiste em "pesquisar as partes de um fenômeno e coleciona-las de modo a ter uma percepção ou conclusão geral" (PASOLD, Cesar Luiz. Metodologia da Pesquisa Jurídica: Teoria e Prática. 13ed.rev. Florianópolis: Conceito Editorial, 2015, p. 91).

${ }^{3}$ REFERENTE: "explicitação prévia dos motivos, objetos e produto desejado, delimitando o alcance temático e de abordagem para uma atividade intelectual, especialmente para uma pesquisa" (Idem, p. $58)$.

${ }^{4}$ CATEGORIA: “a palavra ou expressão estratégica à elaboração e/ou à expressão de uma ideia” (Idem, p. 27).

${ }^{5}$ CONCEITO OPERACIONAL: "definição para uma palavra ou expressão, com o desejo de que tal definição seja aceita para os efeitos das ideias que expomos" (Idem, p. 39)

${ }^{6}$ Adota-se, para a definição de paradigma, a teoria dos paradigmas científicos, de Thomas Kuhn. O paradigma indica "toda uma constelação de crenças, valores, técnicas, etc, partilhadas pelos membros de uma comunidade científica". Tem-se que "uma comunidade científica é formada pelos praticantes de uma especialidade científica. Estes foram submetidos a uma iniciação profissional e a uma educação similares, numa extensão sem paralelos na maioria das outras disciplinas. Neste processo absorveram a mesma literatura técnica e dela retiraram muitas das mesmas lições. Normalmente as fronteiras dessa literatura-padrão marcam os limites de um objeto de estudo científico e em geral cada comunidade possui um objeto de estudo próprio". (KUHN, Thomas S. A estrutura das revoluções científicas. $5^{\mathrm{a}}$ ed., São Paulo: Perspectiva, 1998. Tradução de: Beatriz Vianna Boeira e Nelson Boeira. pp. 218-221)
} 
de que os seres humanos, ao contrário dos animais e das plantas, têm a capacidade de selecionar o seu habitat e adaptá-lo às suas necessidades". ${ }^{7}$

O paradigma ecológico se centrava no indivíduo como unidade de análise (o desenvolvimento social ocorre por meio da adaptação e seleção funcional dos mais aptos em face do ambiente); o controle dos recursos socioespaciais era assumido por aqueles que, na competição, mostravamse mais adaptados, dotados de maior importância funcional na divisão do trabalho. ${ }^{8} 9$

É de se anotar que o paradigma ecológico, que por algum período dominou a sociologia urbana, não se restringiu aos ambientes acadêmicos. Ele projetou efeitos também sobre profissionais da burocracia estatal responsável pelo planejamento urbano. Assim, à compreensão de que a sociologia urbana lhes fornecia bases científicas neutras e imparciais quanto a valores e interesses, agentes estatais justificaram por longo período uma política de intervenção urbanística em conformidade com os desejos das elites sociais dominantes. "Cabia às agências estatais, por meio de uma administração técnica, remediar e controlar os problemas urbanos, os quais eram reduzidos a meras doenças sociais vinculadas à desorganização social". ${ }^{10}$

Ocorre, no entanto, que o paradigma ecológico se mostrou incapaz de fornecer resposta a diversos desafios: pobreza urbana, segregação social e racial, demandas coletivas pelo direito à moradia e agitação político-social nas ruas de diversas metrópoles mundiais etc. Isso gerou uma crise do modelo de cientificidade, uma vez que a naturalização das lógicas urbanas proposta pelo paradigma ecológico ocultava relações de poder no

\footnotetext{
${ }^{7}$ KONZEN, Lucas Pizzolatto. A mudança de paradigma em sociologia urbana: do paradigma ecológico ao socioespacial. In: Revista de Ciências Humanas. Florianópolis, v. 45, n. 1, abr. 2011. p. 83

${ }^{8}$ Idem, p. 84

9 “'Os sociólogos urbanos de Chicago acreditavam na capacidade da sociedade em que viviam de superar os problemas sociais que supunham ser decorrentes de uma situação temporária de desorganização social, desencadeada por mudanças bruscas como o crescimento urbano acelerado, as inovações tecnológicas e a intensa chegada de migrantes. A reorganização social levaria à assimilação das minorias étnicas e dos grupos marginais, bem como à aculturação daqueles cujas atitudes individuais destoavam dos valores sociais predominantes. Neste sentido, estudar cientificamente as desordens sociais concretas confrontadas por Chicago, mas também compartilhadas por outras cidades estadunidenses, permitiria produzir conhecimentos úteis ao seu enfrentamento." (Idem, p. 83)

${ }^{10}$ Idem, p. 85.
} 
espaço urbano e, ainda, disfarçava relações sociais conflituosas ${ }^{11}$, sem oferecer solução a essas questões.

Nesse contexto, abriu-se espaço para o surgimento de um novo paradigma ${ }^{12}$ em sociologia urbana, qual seja, o paradigma socioespacial. Construído a partir das contribuições de diversos autores - mas tendo como maiores expoentes Henri Lefebvre, Manuel Castells e David Harvey, os quais comungavam a inspiração marxista -, o novo paradigma nasceu sustentando que:

[...] as lutas sociais estão ao centro do processo de transformação espacial. Os espaços não são neutros e não existem a priori, mas refletem e modelam a vida social. O espaço não se caracteriza simplesmente por ser um espelho das relações sociais; mais do que isso, ele é também uma fonte de dinâmicas sociais. O espaço representa tanto uma maneira pela qual o passado alcança o presente quanto um modo pelo qual o presente fornece material para construir o futuro. Sem entender a sociedade como um todo, não é possível entender o espaço. Uma teoria do espaço, por conseguinte, consiste em um elemento essencial de uma teoria social abrangente e vice-versa. Com base na premissa da espacialidade das relações sociais forma-se o paradigma socioespacial em sociologia urbana, em torno do qual se aglutinaria toda uma comunidade de cientistas sociais. ${ }^{13}$

Na lógica do novo paradigma socioespacial, as sociedades são especificadas em conformidade com o seu modo de produção e reprodução, organizando-se por classes, relações de propriedade, estados e modos de regulação; o processo de acumulação de capital e a exploração da força de

\footnotetext{
${ }^{11}$ KONZEN, Lucas Pizzolatto. A mudança de paradigma em sociologia urbana: do paradigma ecológico ao socioespacial. p. 85

${ }^{12}$ A mudança de paradigma, ou revolução científica, são "aqueles episódios de desenvolvimento nãocumulativo, nos quais um paradigma mais antigo é total ou parcialmente substituído por um novo". As revoluções científicas têm início "com um sentimento crescente, também seguidamente restrito a uma pequena subdivisão da comunidade científica, de que o paradigma existente deixou de funcionar adequadamente na exploração de um aspecto da natureza, cuja exploração fora anteriormente dirigida pelo paradigma". (KUHN, Thomas S. A estrutura das revoluções científicas. pp. 125-126)

${ }^{13}$ KONZEN, Lucas Pizzolatto. Op.cit. p. 87
} 
trabalho são elementos centrais ao desenvolvimento social. ${ }^{14}$ As interações sociais, desse modo, são marcadas por relações sociais antagônicas, em "uma sociedade estratificada e caracterizada por contradições e padrões de desenvolvimento desiguais" $"$.

Como é possível imaginar, esse novo paradigma não surgiu de forma isolada, mas sim inserido em um novo contexto de teorias sociais que com ele se inter-relacionam e compartilham compreensões. Uma delas - e que vale referir aqui - é a teoria da estruturação, de Anthony Giddens.

De acordo com Giddens, a chave da compreensão dos fenômenos sociais está na relação entre estrutura e ação. Ele refuta sociologias interpretativas que se baseiam exclusivamente no sujeito (funcionalismo etc), assim como aquelas que propõem a centralidade do objeto social (estruturalismo etc). Para Giddens, o domínio básico de estudo das ciências sociais "não é a experiência do ator individual nem a existência de qualquer forma de totalidade social, mas as práticas ordenadas no tempo e no espaço"16.

O conceito de estrutura se refere "às propriedades de estruturação que permitem a delimitação de tempo-espaço em sistemas sociais, [...] que possibilitam a existência de práticas sociais discernivelmente semelhantes por dimensões variáveis de tempo e de espaço" 17. Assim, a estrutura é, em verdade, uma espécie de "ordem virtual" das relações transformadoras, que não existe concretamente, mas que podem ser identificadas como práticas sociais reproduzidas que orientam a conduta de agentes humanos dotados de capacidade cognoscitiva, ainda que eventualmente produzindo resultados não premeditados.

Nesse contexto, segundo a referida teoria,

A coerção estrutural não se expressa em termos das implacáveis formas causais que os sociólogos estruturais têm em mente quando tanto enfatizam a associação de "estrutura" com "coerção". As coerções estruturais não operam independentemente dos motivos e razões dos agentes para o que fazem. [...] Os únicos objetos moventes de relações sociais humanas são os agentes individuais, que empregam recursos para

\footnotetext{
${ }^{14}$ KONZEN, Lucas Pizzolatto. A mudança de paradigma em sociologia urbana: do paradigma ecológico ao socioespacial. p. 88

${ }^{15}$ Ibidem.

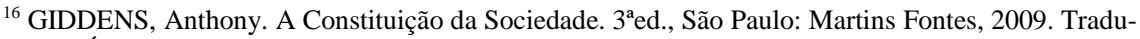
ção de Álvaro Cabral. p. 2

${ }^{17}$ Idem, p. 20
} 
fazer as coisas acontecerem, intencionalmente ou não. As propriedades estruturais de sistemas sociais não atuam ou "agem sobre" alguém como as forças da natureza, para "compelir" o indivíduo a comportar-se de um modo particular. ${ }^{18}$

Em vista disso, pode-se dizer que o espaço urbano, à luz do novo paradigma socioespacial, não pode ser entendido como mero produto de relações e conflitos sociais pré-existentes. Ele é, antes, parte desse processo de interação19 e, inserido no contexto das relações sociais que se dão no tempo e no espaço delimitado, produz efeitos capazes de acentuar ou corrigir desigualdades sociais.

A efetivação do direito à cidade se dá por meio da efetiva apropriação do espaço urbano pelos diferentes grupos sociais. E, considerando as evidentes assimetrias sociais existentes (que se refletem em desigualdades econômicas, políticas, sociais e culturais), não se pode esperar que, de modo natural, seja possível que isso ocorra por meio de políticas urbanísticas elaboradas à luz de "critérios técnicos neutros". As decisões políticas em matéria urbana hão de considerar os efeitos que elas produzem nas relações de poder já existentes no espaço urbano; portanto, é importante que qualquer discussão sobre o melhor modo de estruturação da cidade leve em consideração tais conflitos, a fim de superá-los.

Desse modo, a democratização do espaço urbano pressupõe uma democratização do planejamento urbano estatal, que possibilite políticas transformadoras do espaço urbano e, por consequência, da realidade social.

\section{A SEGREGAÇÃO ESPACIAL URBANA E SEUS REFLEXOS NA PRODUÇÃO LEGISLATIVA URBANÍSTICA}

\footnotetext{
${ }^{18}$ GIDDENS, Anthony. A Constituição da Sociedade. p. 213.

${ }^{19}$ A partir dessa nova compreensão das relações sociais, tem-se a teoria da produção do espaço, de Henri Lefebvre. Para ele, o espaço não é apenas um produto, coisa ou objeto, mas sim um conjunto de relações. Ele, enquanto produto, produz efeitos sobre a própria produção, mediante a organização do trabalho produtivo, transportes, fluxo de matérias-primas e de energias, redes de repartição de produtos. Ele é, a um só tempo, produto e produtor, suporte de relações econômicas e sociais. (LEFEBVRE, Henri. The production of space. Cambridge: Blackwell, 1991. Translated by Donald Nicholson-Smith)
} 
Uma vez compreendida a mudança paradigmática por que passou recentemente a sociologia urbana, transformando a forma de se compreender os fenômenos sociais que ocorrem na cidade - os quais não são mais considerados uma mera consequência da natureza dos processos sociais, mas sim parte integrante e ativa do processo -, passa-se ao exame do problema da segregação espacial, o qual impacta o modo de conformação do espaço urbano e, ainda, produz reflexos sentidos na produção legislativa urbanística.

A segregação espacial, na visão de Manuel Castells, consiste em uma diferenciação produzida no espaço urbano. Define-se como uma "tendência à organização do espaço em zonas de forte homogeneidade social interna e com intensa disparidade social entre elas, sendo esta disparidade compreendida não só em termos de diferença, como também de hierarquia" 20 . Nesse sentido, a segregação urbana atua como um processo em que ocorre uma distribuição diferenciada entre grupos sociais no espaço, o que pode se dar em diferentes níveis de intensidade, respondendo, em qualquer caso, à reprodução das forças de trabalho, bem como das "relações complexas e mutáveis que determinam suas modalidades". ${ }^{21}$

Existem segregações de diferentes naturezas no ambiente urbano. Podem estar assentadas em razões étnicas ou em nacionalidades. No caso brasileiro, não obstante, a espécie de segregação que prepondera são as das diferentes classes ou camadas sociais, as quais, notadamente nas grandes metrópoles, tendem a se concentrar em regiões gerais ou conjuntos de bairros. $^{22}$

Opera-se, assim, uma diferenciação do espaço intraurbano, pois "a ação do conflito de classes em torno das vantagens e desvantagens do espaço urbano" dá ensejo a uma "disputa pela apropriação diferenciada do espaço urbano enquanto produto do trabalho". ${ }^{23}$ De todas as vantagens disputadas, talvez a mais relevante seja o tempo de deslocamento. ${ }^{24}$

\footnotetext{
${ }^{20}$ CASTELLS, Manuel. A questão urbana. Rio de Janeiro: Paz e Terra, 1983. Tradução de: Arlene Caetano. p. 250.

${ }^{21}$ Idem, p. 262.

${ }^{22}$ VILLAÇA, Flávio. Espaço Intra-Urbano no Brasil. São Paulo: Studio Nobel FAPESP, 2001. p. 142

${ }^{23}$ Idem, p. 328

24 “Entende-se por dominação por meio do espaço urbano o processo segundo o qual a classe dominante comanda a apropriação diferenciada dos frutos, das vantagens e dos recursos do espaço urbano. Dentre essas vantagens, a mais decisiva é a otimização dos gastos de tempo despendido nos deslocamentos dos seres humanos, ou seja, a acessibilidade às diversas localizações urbanas, especialmente ao centro urbano. [...] O benefício ou o recurso fundamental que se disputa no espaço urbano é o tempo de
} 
Em relação ao aspecto econômico, a segregação repercute na distribuição do produto entre os indivíduos, o que diz respeito, sobretudo, à moradia. ${ }^{25}$ De um lado, as classes econômicas dominantes se apropriam dos melhores espaços relativos, que propiciem melhores condições de vida e de trabalho. De acordo com Manuel Castells, "a distribuição das residências no espaço produz sua diferenciação social e específica da paisagem". ${ }^{26}$ Isto porque, segundo o autor, as características das moradias - e daqueles que nelas habitam - estão intimamente relacionadas com o tipo e o nível das instalações e das funções que se ligam a elas.

As elites, assim, agrupam-se em regiões gerais ou conjunto de bairros da cidade ${ }^{27}$ e, em um processo natural, atraem para perto de si atividades econômicas relacionadas a comércio e serviços que lhe dão suporte. ${ }^{28}$ Produzem os chamados "novos centros". ${ }^{29}$ Além disso, a valorização imobiliária dessas regiões torna o custo impeditivo para outras classes econômicas de mais baixo padrão, repelindo-as para regiões mais afastadas.

deslocamento. As burguesias produzem para si um espaço urbano tal que otimiza suas condições de deslocamento. Ao fazê-lo, tornam piores as condições de deslocamento das demais classes." (VILLAÇA, Flávio. Espaço Intra-Urbano no Brasil. p. 328)

${ }^{25}$ CASTELLS, Manuel. A questão urbana. Rio de Janeiro: Paz e Terra, 1983. Tradução de: Arlene Caetano. p. 262

${ }^{26}$ Idem, p. 249

27 “[...] o padrão espacial dominante da segregação é segundo setores de círculo, e não segundo círculos concêntricos. Isso ocorre porque o padrão por setores possibilita melhor controle, pela classe dominante, do espaço urbano do que o de círculos concêntricos, uma vez que permite controlar com mais eficiência os deslocamentos espaciais, o mercado imobiliário, o Estado e a ideologia sobre o espaço urbano. Por outro lado, o padrão de segregação destacado não é aquele que se dá em bairros segregados dispersos, mas o que se concretiza de acordo com as grandes regiões segregadas da cidade, onde os bairros das camadas de mais alta renda se aproximam uns dos outros. Com o tempo, os bairros residenciais das elites vão se aglutinando numa mesma região da cidade.” (VILLAÇA, Flávio. Op.cit., p. 335) ${ }^{28}$ É interessante observar que o objetivo da melhor localização relativa da moradia não está relacionada apenas à conveniência. $\mathrm{O}$ padrão de distribuição espacial também objetiva uma distribuição desigual dos riscos a serem suportados pelas diferentes classes sociais. Os ricos podem comprar locais que oferecem melhores condições de moradia em relação à segurança ou às qualidades ambientais, relegando às classes sociais menos favorecidas a sujeição maior a toda ordem de riscos sociais ou ambientais (BECK, Ulrich. Sociedade de Risco: rumo a uma outra modernidade. $2^{\mathrm{a}}$ ed., São Paulo: Editora 34, 2011. Tradução de Sebastião Nascimento. p. 41-42).

29 “Aqueles que ocupam centros 'estabelecem-se' como tendo controles sobre recursos que lhes permitem manter diferenciações entre eles próprios e os que estão nas regiões periféricas. Os estabelecidos podem empregar várias formas de fechamento social para manter a distância de outros que são efetivamente tratados como inferiores ou 'estranhos'. (GIDDENS, Anthony. A Constituição da Sociedade. pp. 154-155) 
Quanto ao plano institucional, como as classes economicamente mais ricas quase sempre coincidem com a classe politicamente dominante, a segregação repercute também em relação à atuação estatal. Neste aspecto, conforme Flávio Villaça, o controle sobre o Estado ocorre por meio de três mecanismos:

A. "o primeiro é a localização dos aparelhos de Estado. [...] tais aparelhos seguem os percursos territoriais das camadas de mais alta renda, da mesma maneira que o comércio e os serviços privados. Suas localizações se comportam exatamente como se estivessem sujeitas às leis de mercado" ;30

B. O segundo mecanismo é a produção da infraestrutura. Há uma concentração dos investimentos públicos nas regiões gerais da cidade ocupadas pelas elites dominantes, em que os serviços são melhores e mais completos. Isso envolve o investimento em vias de transporte (propiciando menor tempo de deslocamento) e melhores serviços e equipamentos públicos (segurança, espaços de lazer, etc);

C. "Finalmente, o Estado atua através da legislação urbanística. Esta, é sabido, é feita pela e para as burguesias. Isso se revela pelo fato de se colocar na clandestinidade e na ilegalidade a maioria dos bairros e das edificações de nossas metrópoles. [...] A maioria dos loteamentos e das edificações realizados para as camadas populares estão impossibilitados - pelas leis do mercado - de obedecer à legislação urbanística e edilícia. Coisa semelhante ocorre com o zoneamento, que é elaborado tendo em vista a solução de problemas dos bairros das classes média e acima da média e o atendimento aos requisitos e padrões urbanísticos dessas classes. O conflito entre usos, um problema menor

\footnotetext{
${ }^{30}$ VILLAÇA, Flávio. Espaço Intra-Urbano no Brasil. pp. 336-337
} 
para os bairros populares, é uma questão central nos zoneamentos convencionais".31 32

Por fim, observa-se que a segregação espacial urbana também produz efeitos ideológicos:

[...] a correspondência entre uma situação social e uma implantação espacial pode reforçar as tendências à autonomização ideológica de certos grupos e levar à constituição de subculturas ecologicamente delimitadas. A segregação pode favorecer a constituição de comunidades que, por um lado, reforçarão ainda mais as distâncias sociais e espaciais e, por outro, dar-lheão um sentido dinâmico, transformando a diferença em contradição. ${ }^{33}$

Como se percebe, segregação espacial urbana impacta o modo como ocorre a apropriação da cidade pelos cidadãos. Ao determinar a concentração de classes sociais dominantes em regiões gerais da cidade, a segregação cria condições de fato desequilibradas, as quais influenciam o planejamento urbano levado a efeito pelo Poder Público.

Essa diferenciação do espaço urbano, como é de se imaginar, produz repercussão na esfera da produção legislativa urbanística e na atuação do poder público de forma geral.

\footnotetext{
${ }^{31}$ VILLAÇA, Flávio. Espaço Intra-Urbano no Brasil. p. 338

${ }^{32}$ De acordo com Maria Coeli Pires, o padrão de segregação que se produz nas cidades é o do caos urbano, em suas múltiplas dimensões: "Numa vertente, ele é compreendido como o estado de maximização das mazelas do urbanismo de risco. Assim, marcado pelo crescimento desordenado das cidades, apresenta, dentre outros impactos, a degradação ambiental, a distribuição desequilibrada do mobiliário urbano, ou seja, dos equipamentos públicos vinculados à prestação de serviços públicos de interesse urbano, e das redes de infraestrutura das funções urbanísticas específicas e essenciais que, em suma e em conjunto, têm repercussão na qualidade de vida dos habitantes, ao tornar o ambiente urbano estressante e insustentável. [...] Esse caos é retratado no perfil socioespacial urbano, que apresenta, de um lado, centralidades e áreas de qualidade de vida vinculadas a uma minoria e, de outro, periferias e áreas de padrões degradantes de habitabilidade, ocupadas pela maior parte da população, em desenho sempre fragmentário. É, também, expresso na forma de nova tensão que se estabelece entre as cidades dos incluídos e as cidades dos excluídos, em substituição à polarização urbano-rural presente até a segunda metade do século XX. (PIRES, Maria Coeli Simões. A função social no direito urbanístico e na política urbana: uma nova ordem de sustentabilidade das cidades. In: PEREIRA, Flavio Henrique Unes; Dias, Maria Tereza Fonseca (Org.). Cidadania e Inclusão Social: Estudos em Homenagem à Professora Miracy Barbosa de Sousa Gustin. Belo Horizonte: Editora Fórum, 2008. p. 379-380)
}

${ }^{33}$ CASTELLS, Manuel. A questão urbana. p. 263 
De um lado, a apropriação do poder político pelas elites econômicas determina que maiores investimentos públicos sejam realizados nas regiões em que elas residem ou desempenham preponderantemente suas atividades; ocorre, em favor dessas regiões, não apenas uma atratividade maior em relação aos empregos, o comércio e serviços, shopping centers e centros empresariais - que se concentram nessas regiões em razão do maior poder aquisitivo de seus moradores -, mas se opera também o deslocamento dos equipamentos públicos e dos aparelhos de Estado. ${ }^{34}$ Assim, investimentos públicos em infraestrutura, redes de transporte, parques e áreas de lazer e serviços de segurança se concentram de modo desproporcional nessas regiões. Criam-se áreas ricas e modernas, as quais nitidamente se diferenciam de áreas pobres e irregulares do ponto de vista da ocupação territorial; opera-se um verdadeiro "apartheid social". ${ }^{35}$

Por outro lado, essa apropriação do poder político impacta também a produção legislativa urbanística; "em nível político-institucional, a 'democracia local' tende a reforçar as consequências da segregação, praticando uma política [...] em função dos interesses da fração dominante $[\ldots]^{\prime \prime} \cdot{ }^{36}$

A desigualdade projetada sobre o poder político privilegia as regiões mais ricas da cidade. O zoneamento urbano é elaborado tendo em consideração os problemas dos bairros de classe média e acima da média, bem como o atendimento de requisitos e padrões urbanísticos dessas classes; e, por consequência, a maioria dos loteamentos e das edificações realizados para as camadas populares ficam impossibilitadas de obedecer à legislação urbanística e edilícia. ${ }^{37}$ Feita pela elite e para a elite, a legislação urbanística não apenas perpetua, mas acentua ainda mais o problema, criando um abismo entre a cidade legal e a cidade ilegal. ${ }^{38}$ Conforme observa Carlos Ari Sundfeld,

A impossibilidade de largas camadas da população terem acesso à propriedade vem sendo tratada como um problema apenas econômico, sem solução específica no campo urbanístico - como se a "ordem

\footnotetext{
${ }^{34}$ VILLAÇA, Flávio. Espaço Intra-Urbano no Brasil. p. 343

${ }^{35}$ SANTOS, Anderson Avelino de Oliveira; ARAÚJO, Marinella Machado. Gestão urbana democrática da cidade por meio do Plano Diretor participativo. Fórum de Direito Urbano e Ambiental, Belo Horizonte, v. 6, n. 36, 2007. p. 11

${ }^{36}$ CASTELLS, Manuel. A questão urbana. p. 262

${ }^{37}$ VILLAÇA, Flávio. Espaço Intra-Urbano no Brasil. p. 338

${ }^{38}$ PINHEIRO, Gabriele Araújo; RODRIGUES, Wagner de Oliveira. Direito fundamental à cidade sustentável e os dilemas do planejamento urbano no Estado Democrático de Direito. Revista da Faculdade de Direito da Universidade de São Paulo, São Paulo, v. 106/107, 2011/2012. p. 378
} 
urbanística" somente fosse possível na abundância. Por óbvio, o mesmo urbanismo elitista que ignora a pobreza é ignorado por ela. O solo urbano passa a ser objeto de ações clandestinas (invasão de imóveis públicos e de espaços comuns, construções irregulares, ocupação de glebas não urbanizadas e de áreas protegidas) e de relações informais (transações de "posses", instalação de serviços e equipamentos públicos em favelas etc). O resultado é a anemia do direito urbanístico, enredado na contradição entre cidade legal e cidade ilegal. ${ }^{39}$

O problema que se coloca, portanto, é como superar essa contradição. Se para o paradigma ecológico a segregação podia ser considerada um processo natural, a mesma questão, ao ser analisada sob o prisma do paradigma socioespacial, deve adquirir outra conotação, devendo ser enfrentada como uma anomalia que afeta o direito à cidade; uma disfunção que põe em risco o equilíbrio e a sustentabilidade urbana.

\section{O PROCESSO DEMOCRÁTICO DE PLANEJAMENTO URBANO COMO ELEMENTO INERENTE À EFETIVAÇÃO DO DIREITO À CIDADE}

Considerados os efeitos da segregação urbana e a influência que ela produz em relação a uma desigual apropriação do espaço urbano, o planejamento urbanístico pode determinar o modo de efetivação do direito à cidade. Se a cidade é determinada pelas relações de poder e conflitos que nela têm lugar, a sua estruturação - resultante do planejamento urbano também haverá de repercutir nas ações sociais que se dão nesse espaço.

$\mathrm{O}$ direito à cidade, tenha-se claro, não constitui um conceito fechado. Ele diz respeito a um conjunto de necessidades humanas relacionadas à estruturação do espaço urbano; é um "plexo de posições jurídicas que, em medidas variáveis, relacionam-se com o bem-estar dos habitantes da

\footnotetext{
${ }^{39}$ SUNDFELD, Carlos Ari. O Estatuto da Cidade e suas Diretrizes Gerais. In: DALLARI, Adilson Abreu; FERRAZ, Sérgio (Org.). Estatuto da Cidade: Comentários à Lei Federal 10.257/2001. 4. ed. São Paulo: Malheiros, 2008. pp. 59-60
} 
cidade" ${ }^{40}$ Trata-se, portanto, de uma construção histórica, própria de cada tempo e lugar.

Intuitivamente, poder-se-ia relacionar o direito à cidade com o direito à moradia; não obstante, embora esse direito esteja naquele compreendido, a isso ele não se restringe. Isso porque "tão relevante quanto garantia da moradia propriamente dita é assegurá-la em condições dignas, o que pressupõe o atendimento de condições mais amplas e não relacionadas a posições jurídicas individuais específicas". ${ }^{41}$ Logo, a realização do direito à cidade passa pela construção de um ambiente urbano sadio para a coletividade, que não realize apenas direitos individuais dos moradores, mas sim um conjunto de direitos coletivos como infraestrutura urbana, serviços essenciais e meio ambiente equilibrado.

É nesse cenário, portanto, que se apresenta relevante a questão do caráter democrático a ser adotado no processo de planejamento urbano. Se há uma variedade de opções de políticas públicas, em um ambiente de circunstâncias complexas, não se recomenda a adoção de soluções intuitivas imediatas. Conforme observa Fernando Alves Correia,

[...] quanto mais a Administração tende a subtrair-se ao domínio da lei, não se apresentando como mera executora da mesma, mas antes dotada de um poder criativo e conformador do direito, tanto mais necessária se torna a participação do cidadão, na dupla perspectiva (subjetiva e objetiva), com a função de "compensar" um poder discricionário que, em alguns sectores, como o da planificação urbanística, atinge uma extensão considerável. Reconhece-se, de facto, que a subordinação da actividade planificatória a um procedimento administrativo, no qual seja reconhecido ao particular o direito de apresentar e de fazer valer as suas próprias razões e os seus próprios interesses, em contraditório com os outros particulares e com os representantes da comunidade e dos vários interesses colectivos, e a consequente obrigação imposta à Administração de levar em consideração, nas opções que vier a tomar no domínio do conteúdo do plano, as

\footnotetext{
${ }^{40}$ REISDORFER, Guilherme F. Dias. Definição e concretização do direito à cidade: entre direitos e deveres fundamentais. Revista de Direito Administrativo Contemporâneo, São Paulo, v. 19, 2015. Ano 3. p. 181

${ }^{41}$ Idem, p. 182
} 
"sugestões" e "observações" dos cidadãos, através de uma motivação suficientemente pormenorizada, constituem limites apreciáveis à liberdade de conformação da Administração. ${ }^{42}$

Nessa perspectiva, o planejamento urbano, direcionado à redução de desigualdades sociais e à redistribuição de riscos e dos benefícios da urbanização, constitui um instrumento fundamental para a efetivação do direito à cidade. ${ }^{43}$ Mas esse instrumento deve ser adotado necessariamente sob a perspectiva democrática, com a participação de uma pluralidade de sujeitos, não apenas os estatais. ${ }^{44}$ Isso se dá porque, considerado o acentuando processo de urbanização por que passam os centros urbanos - transformados em locais de reprodução de distintas desigualdades sociais -, "as normas urbanísticas acabam sendo visualizadas como um instrumento de intervenção social, reconhecendo a cidade como espaço de realizações da sociedade e prescrevendo caminhos para o seu desenvolvimento justo e sustentável". ${ }^{45}$

De acordo com a concepção tradicional de gestão burocrática, preconizavam-se soluções homogêneas para as demandas urbanas. ${ }^{46}$ No entanto, à luz do novo paradigma socioespacial, que põe em questão as relações de poder e os conflitos sociais que ocorrem em cada tempo e lugar, afigura-se relevante que o Poder Público, em resposta aos complexos contextos econômicos e sociais, disponha de mecanismos novos e mais adequados ao processo plural de formulação de políticas públicas urbanas; tais soluções exigem perspectiva democrática, com uma participação social qualificada que não se restrinja à tradicional democracia representativa, incapaz de dar conta da pluralidade de interesses que devem ser contemplados no planejamento urbano.

\footnotetext{
${ }^{42}$ CORREIA, Fernando Alves. Manual de Direito do Urbanismo. 4. ed. Coimbra: Almedina, 2012. pp. 448-449

${ }^{43}$ FERREIRA, Gabriel Luis Bonora Vidrih. Plano Diretor e Inclusão Social no Espaço Urbano. In: Revista de Direitos Difusos, Rio de Janeiro, v. 46, 2008. p. 36

${ }^{44}$ Neste ponto, é relevante observar que não a participação dos cidadãos no processo de planejamento urbano não pode se restringir àquelas que sejam proprietários ou titulares de outros direitos reais que incidam sobre imóveis situados na cidade; deve, ao contrário, abarcar um círculo muito mais amplo, incluindo todo e qualquer cidadão que vivencie a experiência da cidade e que tenha interesse na melhoria da qualidade de vida do lugar em que habita (vide CORREIA, Fernando Alves. Manual de Direito do Urbanismo. p. 449)

${ }^{45}$ FERREIRA, Gabriel Luis Bonora Vidrih. Plano Diretor e Inclusão Social no Espaço Urbano. p. 29

${ }^{46}$ PIRES, Maria Coeli Simões; COSTA, Mila Batista Leite Corrêa da. Sustentabilidade e função social do espaço urbano: direito à cidade e ressignificação. In: Revista Brasileira de Direito Municipal, Belo Horizonte, v. 15, n. 53, 2014 p. 77-78
} 
O regime urbanístico adotado no art. 182 da Constituição da República de $1988^{47}$ está justamente baseado nessa nova perspectiva. A Constituição, pela primeira vez, delineou com maior nitidez o campo temático do direito urbanístico. Definiram-se conceitos (função social da propriedade urbana, planejamento urbanístico, utilização compulsória etc) e objetivos (desenvolvimento urbano, regularização fundiária, proteção ambiental etc), distribuiram-se competências (entre União, Estados e Municípios) e, ainda, colocaram-se à disposição do Poder Público inúmeros instrumentos de intervenção urbana (desapropriação urbanística, licença urbanística, plano diretor etc). ${ }^{48}$

Não obstante, foi o Estatuto da Cidade ${ }^{49}$ que, de forma mais minuciosa, estabeleceu em seu art. $40, \S 4^{\circ}$, que, no processo de elaboração do plano diretor e na fiscalização de sua implementação, os Poderes Legislativo e Executivo municipais devem garantir: (i) a promoção de audiências públicas e debates com a participação da população e de associações representativas dos vários segmentos da comunidade; (ii) a publicidade quanto aos documentos e informações produzidos; (iii) o acesso de qualquer interessado aos documentos e informações produzidos.

A participação popular no processo de elaboração do plano diretor, tal como disciplinada no Estatuto da Cidade, constitui assim um elemento fundamental na democratização da gestão urbana, em especial no que tange ao objetivo de "fortalecer o elo entre a cidade real, a cidade ideal e a cidade possível de se realizar" ${ }^{50}$. A legitimação do plano diretor, nesse contexto, não decorre apenas de sua veiculação por meio de lei em sentido formal, mas sim de um prévio e qualificado processo participativo de elaboração (inclusive na fase pré-legislativa) em que a população e as entidades representativas da sociedade civil organizada, possam participar diretamente da definição das mais diversas questões municipais, observadas as suas peculiaridades, demandas e interesses específicos. ${ }^{51}$ Trata-se de um

\footnotetext{
47 BRASIL. Constitucional da República Federativa do Brasil de 1988. Disponível em: <http://www.planalto.gov.br/ccivil_03/constituicao/constituicao.htm>. Acesso em: <25.03.2017>

${ }^{48}$ SUNDFELD, Carlos Ari. O Estatuto da Cidade e suas Diretrizes Gerais. pp. 52-53

${ }^{49}$ BRASIL. Lei n. 10.257, de 10 de julho de 2001. Disponível em: <http://www.planalto.gov.br/ccivil_03/leis/LEIS_2001/L10257.htm>. Acesso em: 25.03.2017.

${ }^{50}$ GONDIM, Linda Maria de Pontes; LIMA, Martônio Mont'alverne Barreto; MOREIRA, Sandra Mara Vale. Democracia, tecnocracia e política: encontros e desencontros na elaboração do plano diretor participativo. In: Revista Interesse Público, Porto Alegre, v. 35, 2006. pp. 269-270

${ }^{51}$ Idem, pp. 281-282
} 
processo decisório aberto em que se promove o efetivo exercício da cidadania. $^{52}$

Ao se examinar o disposto no art. $40, \S 4^{\circ}$, do Estatuto da Cidade, verifica-se que houve a definição de que a democratização do processo de elaboração do plano diretor deve se dar em três aspectos distintos. Em primeiro lugar, há previsão de que deve ser conferida absoluta publicidade aos documentos e informações que embasam o processo de discussão e elaboração do plano diretor; trata-se, por certo, de uma atuação ativa, consubstanciada no dever do Poder Público (aqui compreendido tanto o Legislativo quanto o Executivo) de tornar públicas as informações relacionadas ao processo, seja por meio físico ou digital, mesmo antes de ser instado a fazê-lo. ${ }^{53}$ Um segundo aspecto, por outro lado, diz respeito ao dever do Poder Público de prestar informações que lhe sejam requeridas. Esse dever possibilita que qualquer interessado possa requerer tais informações e obtêlas em prazo razoável. E, por fim, o Estatuto da Cidade estabelece que o Poder Público tem o dever de criar as oportunidades de manifestação da sociedade, o que se dá através da realização de audiências públicas e debates em que sejam postos à apreciação e explicitados, em linguagem acessível $^{54}$, os aspectos técnicos do projeto. ${ }^{55}$

Assim, deve-se compreender que o Estatuto da Cidade prevê que não apenas deve haver participação popular no processo de elaboração do plano diretor, mas também que essa participação deve ser informada, qualificada, instruída. Devem ser divulgadas com antecedência necessária as informações a serem discutidas pelos interessados em audiências; deve haver a divulgação dos comentários e sugestões formulados, bem como resposta fundamentada a quaisquer comentários e contribuições. ${ }^{56} \mathrm{O}$ caráter substancial - e não apenas formal - que se espera desse processo colaborativo de elaboração do plano diretor exige que as contribuições sejam

\footnotetext{
${ }^{52}$ MUKAI, Toshio. O Estatuto da Cidade. In: CARDOSO, José Eduardo Martins; QUEIROZ, João Eduardo Lopes; SANTOS, Márcia Walquiria Batista dos (Org.). Direito Administrativo Econômico. São Paulo: Editora Atlas, 2011. p. 1425

${ }^{53}$ CÂMARA, Jacintho Arruda. Plano Diretor. In: DALLARI, Adilson Abreu; FERRAZ, Sérgio (Org.). Estatuto da Cidade: Comentários à Lei Federal 10.257/2001. 4. ed. São Paulo: Malheiros, 2014. p. 339

${ }^{54}$ SOUZA, Guilherme Carvalho e. A importância da gestão democrática das cidades para a formulação de políticas públicas no âmbito municipal: a criação do plano diretor. Revista Brasileira de Direito Municipal, Belo Horizonte, v. 12, n. 42, 2011. p. 96

${ }^{55}$ GASPARINI, Diógenes. Aspectos jurídicos do plano diretor. Interesse Público, Porto Alegre, v. 31, 2005. P. 18-19

${ }^{56}$ CÂMARA, Jacintho Arruda. Op.cit. p. 339
} 
efetivamente consideradas pelo gestor, o qual, para rejeitá-las, deve expor as razões que o justificam. O objetivo é que desse processo, após um debate amplo e qualificado, possa resultar um plano diretor mais adequado às necessidades e especificidades dos diferentes grupos sociais que integram o espaço urbano.

\section{CONSIDERAÇÕES FINAIS}

A transição paradigmática pela qual passou a sociologia urbana nos últimos anos impôs uma significativa reformulação no modo como devem ser analisadas as questões urbanas. Se, antes, na lógica do paradigma ecológico, os problemas urbanos eram tidos como anomalias temporárias de um processo natural de adaptação, o novo paradigma socioespacial põe em questão a efetiva existência relações de poder e conflitos sociais que se estabelecem no tempo e no espaço. Logo, para a solução dos problemas urbanos, não há critérios neutros e imparciais que possam ser adotados em qualquer tempo e lugar pela burocracia estatal, como antes se acreditava. Essa concepção atendia a um modelo de cientificidade que já pode ser tido como superado.

Dentre os fenômenos urbanísticos que devem ser problematizados - tendo em consideração suas razões e efeitos -, destacou-se, no presente estudo, a segregação espacial urbana. Em lugar de considerá-la um processo naturalístico, evidenciou-se que ela decorre de conflitos de interesse de diferentes grupos sociais, produzindo modificações no modo como ocorre a apropriação do espaço urbano. Tais efeitos, geradores de significativa desigualdade, tem projeção não apenas em termos econômicos e ideológicos, mas também político-institucionais, pois influenciam decisivamente a produção legislativa urbanística estatal e os investimentos públicos em diferentes regiões da cidade.

Nesse contexto, procurou-se demonstrar, à guisa de conclusão, que a efetivação do direito à cidade - este entendido como um conceito aberto, construído a partir de um feixe de direitos que se inter-relacionam no espaço urbano e que são necessários ao bem-estar dos habitantes - passa necessariamente por um processo de planejamento urbano de viés democrático. A participação social no processo de elaboração das políticas urbanas - com a pluralidade de sujeitos (não apenas os estatais) e de concepções (não apenas as da classe dominante) - constitui requisito 
indispensável para mitigar os efeitos desiguais que fenômenos, como a segregação espacial, produzem no espaço urbano. É preciso a existência de mecanismos que impeçam que, em termos urbanísticos, o exercício do poder político seja mera projeção dos interesses do poder econômico.

No âmbito do regime urbanístico brasileiro, o principal mecanismo de pluralização da produção legislativa urbanística é o Plano Diretor Urbano. Enquanto a Constituição Federal atribuiu ao Plano Diretor o status de instrumento básico da política de desenvolvimento e expansão urbana, o Estatuto da Cidade estabeleceu um rito procedimental especial para a sua elaboração e aprovação, o qual prevê intensa participação social, com a realização de audiências, debates, ampla publicidade, etc. Nesse cenário, a centralidade do Plano Diretor na política urbana e o seu rito democrático de elaboração e aprovação faz com que ele possa ser tido como um interessante instrumento apto a mitigar efeitos de desigualdades econômicas e propiciar uma apropriação mais democrática do espaço urbano. Ele é o ponto de partida do que deve ser entendido como gestão democrática das políticas urbanas.

\section{REFERÊNCIAS BIBLIOGRÁFICAS}

BECK, Ulrich. Sociedade de Risco: rumo a uma outra modernidade. $2^{\mathrm{a}}$ ed., São Paulo: Editora 34, 2011. Tradução de Sebastião Nascimento.

BRASIL. Constitucional da República Federativa do Brasil de 1988. Disponível e: <http://www.planalto.gov.br/ccivil_03/constituicao/constituicao.htm>. Acesso em: $\langle 25.03 .2017\rangle$.

BRASIL. Lei n. 10.257, de 10 de julho de 2001. Disponível em: <http://www.planalto.gov.br/ccivil_03/leis/LEIS_2001/L10257.htm>. Acesso em: 25.03.2017.

CÂMARA, Jacintho Arruda. Plano Diretor. In: DALLARI, Adilson Abreu; FERRAZ, Sérgio (Org.). Estatuto da Cidade: Comentários à Lei Federal 10.257/2001. 4. ed. São Paulo: Malheiros, 2014. p. 323-343

CASTELLS, Manuel. A questão urbana. Rio de Janeiro: Paz e Terra, 1983. Tradução de: Arlene Caetano.

CORREIA, Fernando Alves. Manual de Direito do Urbanismo. 4. ed. Coimbra: Almedina, 2012.

FERREIRA, Gabriel Luis Bonora Vidrih. Plano Diretor e Inclusão Social no Espaço Urbano. In: Revista de Direitos Difusos, Rio de Janeiro, v. 46, p.29-39, 2008. 
GASPARINI, Diógenes. Aspectos jurídicos do plano diretor. In: Revista Interesse Público, Porto Alegre, v. 31, pp. 13-37, 2005.

GIDDENS, Anthony. A Constituição da Sociedade. $3^{\mathrm{a} e d}$., São Paulo: Martins Fontes, 2009. Tradução de Álvaro Cabral.

GONDIM, Linda Maria de Pontes; LIMA, Martônio Mont'alverne Barreto; MOREIRA, Sandra Mara Vale. Democracia, tecnocracia e política: encontros e desencontros na elaboração do plano diretor participativo. In: Revista Interesse Público, Porto Alegre, v. 35, p.269-289, 2006.

KONZEN, Lucas Pizzolatto. A mudança de paradigma em sociologia urbana: do paradigma ecológico ao socioespacial. In: Revista de Ciências Humanas. Florianópolis, v. 45, n. 1, pp. 79-99, abr. 2011.

KUHN, Thomas S. A estrutura das revoluções científicas. $5^{\text {a }}$ ed., São Paulo: Perspectiva, 1998. Tradução de: Beatriz Vianna Boeira e Nelson Boeira.

LEFEBVRE, Henri. The production of space. Cambridge: Blackwell, 1991. Translated by Donald Nicholson-Smith.

MUKAI, Toshio. O Estatuto da Cidade. In: CARDOSO, José Eduardo Martins; QUEIROZ, João Eduardo Lopes; SANTOS, Márcia Walquiria Batista dos (Org.). Direito Administrativo Econômico. São Paulo: Editora Atlas, 2011. pp. 1408-1427

PASOLD, Cesar Luiz. Metodologia da Pesquisa Jurídica: Teoria e Prática. 13ed.rev. Florianópolis: Conceito Editorial, 2015.

PINHEIRO, Gabriele Araújo; RODRIGUES, Wagner de Oliveira. Direito fundamental à cidade sustentável e os dilemas do planejamento urbano no Estado Democrático de Direito. In: Revista da Faculdade de Direito da Universidade de São Paulo, São Paulo, v. 106/107, p.373-387, 2011/2012.

PIRES, Maria Coeli Simões. A função social no direito urbanístico e na política urbana: uma nova ordem de sustentabilidade das cidades. In: PEREIRA, Flavio Henrique Unes; Dias, Maria Tereza Fonseca (Org.). Cidadania e Inclusão Social: Estudos em Homenagem à Professora Miracy Barbosa de Sousa Gustin. Belo Horizonte: Editora Fórum, pp. 377-405, 2008.

PIRES, Maria Coeli Simões; COSTA, Mila Batista Leite Corrêa da. Sustentabilidade e função social do espaço urbano: direito à cidade e ressignificação. In: Revista Brasileira de Direito Municipal, Belo Horizonte, v. 15, n. 53, p.7387, 2014.

REISDORFER, Guilherme F. Dias. Definição e concretização do direito à cidade: entre direitos e deveres fundamentais. In: Revista de Direito Administrativo Contemporâneo, São Paulo, v. 19, p.177-197, 2015. Ano 3.

SANTOS, Anderson Avelino de Oliveira; ARAÚJO, Marinella Machado. Gestão urbana democrática da cidade por meio do Plano Diretor participativo. In: Fórum de Direito Urbano e Ambiental, Belo Horizonte, v. 6, n. 36, p.10-15, 2007.

SOUZA, Guilherme Carvalho e. A importância da gestão democrática das cidades para a formulação de políticas públicas no âmbito municipal: a criação do 
plano diretor. In: Revista Brasileira de Direito Municipal, Belo Horizonte, v. 12, n. 42, 2011.

SUNDFELD, Carlos Ari. O Estatuto da Cidade e suas Diretrizes Gerais. In: DALLARI, Adilson Abreu; FERRAZ, Sérgio (Org.). Estatuto da Cidade: Comentários à Lei Federal 10.257/2001. 4. ed. São Paulo: Malheiros, 2008. p. 45-62.

VILLAÇA, Flávio. Espaço Intra-Urbano no Brasil. $1^{\mathrm{a} e d}$., São Paulo: Studio Nobel FAPESP, 2001. 